ORIGINALN I ČLANAK

\title{
Relationship between body composition and postural disorder in goalball athletes: pilot study
}

\section{Povezanost telesne kompozicije i posturalnih poremećaja golbal igrača}

\author{
Stefan Đorđević, Fakultet sporta i fizičkog vaspitanja, Niš \\ Nebojša Mitrović, Pedagoški fakultet, Istočno Sarajevo, BiH \\ Jovana Zrnzević, Internacionalni paraolimpijski komitet, Bon, Nemačka \\ Martin Kudlaček, Fakultet telesne kulture, Olomouc, Češka \\ Bojan Jorgić, Fakultet sporta i fizičkog vaspitanja, Niš
}

\begin{abstract}
Goalball is one of the most popular ball sports for people with visual disability. Like other sports, goalball offers the benefit of developing one's physical abilities as well as affecting overall development; however, due to its specific characteristics, it can also have undesirable

Keywords:

Scoliosis,

Fat mass, side effects. In view of this fact, the objective of this study was to determine the relationship between the parameters of body composition and postural status in goalball players. The study participants included 38 male goalball players with the mean age of $27.89 \pm 8.4$ competing Correlation at the international and national levels of goalball representation Group $\mathrm{C}$. The measuring tool TANITA TBW 300 was used to assess body composition parameters, whereas the Spinal Mouse instrument was used for the assessment of postural status parameters among the goalball players. In order to assess the correlation between the two sets of variables (body composition and postural status), correlational analysis between two sets of variables was used. The obtained results reveal a correlation at the level of significance $p=0.05$ between the angle of the scoliotic curvature in the thoracic area of the spinal column on the one hand, and body mass index on the other, whereas the correlation of body fat percentage and the mass was at the level of $p=0.01$. No statistically significant correlation was found between the remaining variables. The results obtained indicate increased incidence of deformity both in the sagittal and in the frontal planes of the spinal column; furthermore, the testing of body composition parameters pertaining to fat returned very high results in this group of goalball players.
\end{abstract}


SAŽETAK

Ključne reči:
skolioza,
masti,
korelacija
Golbal predstavlja jedan od najpopularnijih sportova sa loptom osoba sa vizuelnim invaliditetom. Kao i ostali sportovi ovaj sport pruža mogućnost razvoja fizičkih sposobnosti i razvoj organizma u celosti, ali usled svojih specifičnosti može da dovede i do neželjenih efekata. Iz tog razloga, cilj ovog rada bio je da se utvrdi povezanost između parametara telesne kompozicije i posturalnog statusa igrača golbala. Ovim istraživanjem obuhvaćeno je 38 igrača golbala muškog pola prosečne starosti $27,89 \pm 8,4$ međunarodnog i nacionalnog nivoa koji pripadaju C grupi ranga reprezentacija golbala. Za procenu parametara telesne kompozicije korišćen je instrument TANITA TBW 300 a za procenu parametara posturalnog statusa igrača korišćen je instrument "Spinal Mouse". Za izračunavanje međusobne povezanosti dva seta varijabli (telesne kompozicije i posturalnog statusa) korišćena je korelaciona analiza između dva seta varijabli. Na osnovu dobijenih rezultata može se zaključiti da postiji korelacija na nivou značajnosti od $p=0,05$ između ugla skoliotične krivine u torakalnom delu kičmenog stuba sa težinom, sa indeksom telesne mase, zatim sa procentom telesne masti i količinom telesne masti. Među ostalim varijablama nije bilo statistički značajne korelacije. Dobijeni rezultati su ukazali na povećanu učestalost deformiteta kako u sagitalnoj tako i u frontalnoj ravni kičmenog stuba, a takođe i parametri telesne kompozicije koji su vezani za masti pokazali su veoma visok nivo kod ove grupe igrača golbala.

\section{Introduction}

Goalball is one of the most popular team ball sports for people with visual disability. This sport, like other team Olympic sports played using a ball, is classified as an anaerobic acyclic sport (Calıskan et al., 2011). Competitions for this game are organized for men and for women athletes, at the national and international levels. Given its specific character, this sport may promote increased activity of the shoulder area and of the dominant hand used when shooting at the opponent's goal. In case of inadequate coaching and training, this distinctive feature may lead to an impairment of the balance of muscle group strength and of postural status (Grabara \& Hadzik, 2009a; Grabara \& Hadzik, 2009b; Slawinska, Rozek, \& Ignasiak, 2006).

A postural status can serve as indicator of the existence of balance between the skeleto-muscular system and locomotor apparatus during movement and at rest (Demeši-Drljan \& Mikov, 2012). The postural status of the spinal column can be assessed from the frontal or sagittal plane. When correct postural status in the sagittal plane is adversely affected, this can result in deformity in the thoracic and lumbar areas of the spine, such as kyphosis and lordosis (Milenković, 2007). In addition to these two deformities, flat back deformity can occur in the sagittal plane as a consequence of insufficient physiological curving of the spinal column. In addition to postural disorders of the sagittal plane, the disorders in the frontal plane can also occur, such as scoliotic bad posture (Živković, 2009).

Body composition refers to a group of indicators pertaining to a range of health parameters, obesity, and the percentage of body fat, water and muscle in body composition, namely those features which, mostly in the form of health parameters, characterize an athlete (Bjorntorp, 1990; Karaba-Jakovljević, 2016).

Goalball players' body composition is an important consideration for a number of reasons, in particular in view of the insufficient physical activity which tends to characterize persons affected by visual disability (Colak, Bamac, Aydin, Meric, \& Ozbek, 2004) as well as considering the low levels of goalball development compared to other sports in our region. Furthermore, body composition parameters may indicate, albeit indirectly, the athlete's current status regarding his or her endurance and stamina.

Given the scarcity of studies into the morphological profile of goalball players, there has also been insufficient research into their postural status (Scherer, Karasiak, Silva, \& Petroski, 2012). Therefore, the objective of this paper is to examine the correlation between the parameters of body composition and postural status in goalball players. 
Đorđević, S., Mitrović, N., Zrnzević, J., Kudlaček, M., Jorgić, B. - Body composition and postural disorder in goalball 2018. Fakultet za sport i turizam, Novi Sad, Tims.Acta 12, 17-23

\section{Methodology}

\section{Subjects}

The subject sample comprised 38 male goalball players competing at the international and national levels, globally ranking in Group C. All study participants were between 15 and 45 years of age.

\section{Measure instruments}

The measure instrument TANITA TBF 300, BODY COMPOSITION ANALYZER GOAL SETTER (USA) was used for the assessment of goalball players' body composition status. A range of academic studies have used this instrument over the past ten years with the aim of determining the status of athletes' body composition (Abdelkrim, El Fazaa, \& El Ati, 2007; Haroun et al., 2010; Farajian et al., 2011). Measurement results for body composition are presented by the following variables: BMI - Body Mass Index, FAT \% - the percentage of total body weight that is fat, FAT MASS - total weight of fat mass.

The 'Spinal Mouse' instrument was used in assessing goalball athlete spinal postural status (Idiag, Fehraltdorf, Switzerland). This instrument uses a non-invasive method for the assessment of spinal column postural status. Several studies (Mannion, Knecht, Balaban,
Dvorak, \& Grob, 2004; Post \& Leferink 2004) have ascertained the validity and reliability of results obtained using this particular measure instrument. Moreover, a number of studies have used this instrument as a mean for the assessment of spinal column postural status in subjects of various ages (Bubanj, et al., 2012; Jorgić, Milenković, Milenković, Stanković, \& Bubanj, 2015; Jorgić et al., 2016). The results of measuring spinal column postural status are presented using the following variables: $\mathrm{KYPH}$ - angle of kyphotic spinal curvature, LOR - angle of lordotic spinal curvature, SCLT - angle of scoliotic spinal curvature in the thoracic area, and SCLL - angle of scoliotic spinal curvature in the lumbar area and ND - no deformity.

\section{Statistical analysis}

All data obtained in this study were processed using the SPSS 20 statistical package. Descriptive statistics parameters for all variables were calculated, namely central and dispersive parameters, including: arithmetic mean (AM); standard deviation (SD); results range (R); minimum result (Min); and maximum result (Max). Regarding postural status parameters, in order to obtain a more precise explanation, incidence (in percentage) was calculated. Correlational analysis was used in order to assess the correlation between the two focal sets of variables (body composition and postural status).

\section{Results}

Table 1. Descriptive statistics for the set of variables describing goalball players' body composition.

\begin{tabular}{cccccc}
\hline & \multicolumn{3}{c}{ Descriptive Statistics } & Std. Deviation \\
\hline & $\mathrm{N}$ & Minimum & Maximum & Mean & Statistic \\
\hline & Statistic & Statistic & Statistic & Statistic & 8.40 \\
\hline BGE & 38 & 15.00 & 45.00 & 27.89 & 5.02 \\
\hline FAT & 38 & 17.90 & 44.00 & 27.25 & 8.10 \\
\hline FATMASS & 38 & 3.80 & 35.60 & 17.28 & 10.26 \\
\hline BMI - Body Mass Index, FAT \% - The percentage of total body weight that is fat, FAT MASS - Total weight of fat \\
\hline
\end{tabular}

Table 1 presents descriptive statistics parameters for the variable set body composition. The results for BMI means stand out somewhat, indicating that the subjects have increased BMI values, and classifying these participants in the pre-obese group. 
Đorđević, S., Mitrović, N., Zrnzević, J., Kudlaček, M., Jorgić, B. - Body composition and postural disorder in goalball 2018. Fakultet za sport i turizam, Novi Sad, Tims.Acta 12, 17-23

Table 2. Descriptive statistics for the set of variables describing goalball players' spinal postural status.

\begin{tabular}{|c|c|c|c|c|c|}
\hline \multicolumn{6}{|c|}{ Descriptive Statistics } \\
\hline & $\mathrm{N}$ & Minimum & Maximum & Mean & Std. Deviation \\
\hline & Statistic & Statistic & Statistic & Statistic & Statistic \\
\hline Kyph & 38 & 0.00 & 62.00 & 40.84 & 16.00 \\
\hline Lor & 38 & 1.00 & 43.00 & 23.05 & 11.71 \\
\hline Sclt & 38 & 0.00 & 16.00 & 5.44 & 4.68 \\
\hline Scll & 38 & 0.00 & 15.00 & 6.02 & 3.72 \\
\hline Valid N (listwise) & 38 & & & & \\
\hline
\end{tabular}

Results in Table 2 present the subjects' descriptive statistics for the variable set postural status of the spinal column in the frontal and sagittal planes. The results indicate the mean value for kyphotic spinal curvature at $40.84 \pm 16,00$ degrees, which falls within the typical range, with the reference values in the 35 to 47 degree range as measured by the Spinal Mouse instrument. The results obtained for the lumbar area of the sagittal plane also fall within the typical values, with lordosis mean at
$23.05 \pm 11.71$ compared to the reference values in the range between 20 and 35 degrees, also measured by the Spinal Mouse. Results obtained for postural status in the frontal plane indicate that the subjects had on average scoliotic posture values lower than $15^{\circ}$ in the thoracic $(5.44 \pm 4.68)$ and lumbar areas (6.02 \pm 3.72$)$, which is considered functional scoliosis, or first-degree scoliosis (Živković, 2009).

Table 3. Incidence of spinal deformity in goalball athlete sagittal plane, in percentages.

\begin{tabular}{|c|c|c|c|c|c|}
\hline \multicolumn{4}{|c|}{ Kyphosis } & \multicolumn{2}{|c|}{ Lordosis } \\
\hline & & Frequency & Percent & Frequency & Percent \\
\hline \multirow{4}{*}{ Valid } & No deformity & 20 & 52.60 & 22 & 57.90 \\
\hline & First level of deformity & 12 & 31.60 & 6 & 15.80 \\
\hline & $\begin{array}{l}\text { Flat back in thoracic and lumbar areas of } \\
\text { the spine }\end{array}$ & 6 & 15.80 & 10 & 26.30 \\
\hline & Total & 38 & 100.00 & 38 & 100.00 \\
\hline
\end{tabular}

Results presented in Table 3 indicate that 20 goalball players have no deformity in the thoracic area of the sagittal plane, while 12 participants have a diagnosis of kyphotic deformity, and 6 have a diagnosis of flat back deformity in the thoracic area of the spinal sagittal plane. Furthermore, results pertaining to the lumbar area of the sagittal plane of the spine indicate that 22 subjects have no deformity, whereas 6 subjects have lordotic bad posture, and 10 players have flat back deformity in the lumbar area of the sagittal plane.

Table 4 results indicate the presence of scoliotic bad posture in the frontal plane of the thoracic area in 11 goalball players, whereas no deformity was found in 27 study participants; further, scoliotic bad posture in the lumbar area of the frontal plane was found in 15 subjects, while no scoliosis was found in 23 subjects.

Table 5 presents correlational statistics results using the Pearson correlation coefficient between two groups or sets of variables, namely spinal column postural status and body composition in goalball players. These results indicate a statistically significant correlation with a level of significance $p=0.05$ only between the variable size of scoliotic curvature angle in the thoracic area of the spine and the variables goalball athlete BMI, whereas the significance is $p=0.01$ regarding variables FAT and FAT MASS. 
Đorđević, S., Mitrović, N., Zrnzević, J., Kudlaček, M., Jorgić, B. - Body composition and postural disorder in goalball 2018. Fakultet za sport i turizam, Novi Sad, Tims.Acta 12, 17-23

Table 4. Incidence of goalball athlete spinal column deformity in the frontal plane, in percentages.

\begin{tabular}{|c|c|c|c|c|c|}
\hline \multicolumn{4}{|c|}{ Scoliosis in the thoracic area } & \multicolumn{2}{|c|}{ Scoliosis in the lumbar area } \\
\hline & & Frequency & Percent & Frequency & Percent \\
\hline \multirow{3}{*}{ Valid } & No deformity & 27 & 71,1 & 23 & 60,5 \\
\hline & $\begin{array}{l}\text { Functional scoliosis } \\
\text { (I degree) }\end{array}$ & 11 & 28,9 & 15 & 39,5 \\
\hline & Total & 38 & 100,0 & 38 & 100,0 \\
\hline
\end{tabular}

Table 5. Correlations between the variable sets spinal column postural status and goalball athlete body composition.

\begin{tabular}{|c|c|c|c|c|}
\hline \multicolumn{5}{|c|}{ Correlations } \\
\hline & & BMI & FAT & FATMASS \\
\hline \multirow{3}{*}{ kyph } & Pearson Correlation &, 087 & ,122 & ,116 \\
\hline & Sig. (2-tailed) &, 604 & ,464 & ,487 \\
\hline & $\mathrm{N}$ & 38 & 38 & 38 \\
\hline \multirow{3}{*}{ lor } & Pearson Correlation & ,192 & ,127 & ,176 \\
\hline & Sig. (2-tailed) & ,248 & ,449 & 290 \\
\hline & $\mathrm{N}$ & 38 & 38 & 38 \\
\hline \multirow{3}{*}{ sclt } & Pearson Correlation &, $410^{*}$ &, $469^{\star \star}$ &, $471^{\star \star}$ \\
\hline & Sig. (2-tailed) & 011 &, 003 &, 003 \\
\hline & $\mathrm{N}$ & 38 & 38 & 38 \\
\hline \multirow{3}{*}{ scll } & Pearson Correlation &,- 013 &,- 120 &,- 106 \\
\hline & Sig. (2-tailed) & ,938 &, 472 & ,528 \\
\hline & $\mathrm{N}$ & 38 & 38 & 38 \\
\hline \multicolumn{5}{|c|}{ *. Correlation is significant at the 0.05 level (2-tailed). } \\
\hline & $\star *$. Correlatio & $t$ at the & tailed). & \\
\hline
\end{tabular}

BMI - Body Mass Index, FAT \% - The percentage of total body weight that is fat, FAT MASS - Total weight of fat mass, kyph - angle of kyphotic curvature in the spinal column, lor - angle of lordotic curvature of the spine, sclt - angle of scoliotic curvature of the thoracic area of the spinal column, and scll - angle of scoliotic curvature of the lumbar area of the spine.

\section{Discussion}

The results obtained in this study indicate the current state of postural status and body composition in thirdlevel goalball players participating in international and national competitions. Based on the values obtained for variable sets pertaining to postural status of the spinal column in the sagittal and frontal planes, there is a considerably high incidence of deformity in this sample. For the thoracic area of the sagittal plane, kyphosis and flat back syndrome were found in 18 subjects, or $47.4 \%$, whereas for the lumbar area of the sagittal plane lordosis and flat back were found in 16 study participants, or $42.1 \%$. Scoliotic deformity was found in 11 subjects, or $28.9 \%$, in the thoracic area, and in 15 subjects, or $39.5 \%$, in the lumbar area, making it, individually considered, the deformity with the highest incidence among the study's participants. Thus, the obtained results confirm the findings of earlier studies of the incidence levels of scoliotic bad posture in persons with visual disability, both in the younger and in the older population (Bolach \& Skolimowski, 2000; Catanzariti, Salomez, Bruandet, \& Thevenon, 2001). Similarly, regarding the second variable set, pertaining to the state of body composition in goalball players, the parameters, or variables, describing the fat tended to indicate that the average values were such that they placed the subjects in the at-risk group for pre-obesity, with a BMI mean at $27.2526 \pm 5.00$; FAT $\%$ at $17.28 \pm 8.1$ and FAT MASS $16.14 \pm 10.26$, which agrees with the results obtained for goalball players in the study 
signed by Scherer, Karasiak, Silva, \& Petroski (2012), where higher results for fat parameters were also found. In accordance with the results obtained in the present study, results of earlier studies indicated that persons with visual disability tended to be more overweight than persons who had no such disability (Hopkins, Gaeta, Thomas, \& Hill, 1987). An explanation for such results may be found in insufficient physical activity and attendant stamina in this group of goalball players.

The results of correlational statistics between postural status and body composition indicate a statistically significant relationship between scoliotic bad posture in the thoracic area and body composition variables pertaining to fat (BMI, FAT\% and FAT MASS). The results obtained can be explained by the specific character of the goalball game, where a cluster of technical elements during offense on the opponent's goal is mostly performed by one, the dominant, side of the body. This holds for the shoulder and arm areas in particular, which can influence the emergence of scoliotic bad posture deformity in the thoracic area of the spine on the frontal plane. Also, based on body composition parameters, this subject sample can be classified as at risk of pre-obesity, which indicates that the fat percentage is higher in the sample; consequently, the percentage of muscle mass is lower in this group, and, in view of the specific nature of goalball, muscle mass is concentrated precisely in the area with most muscular activity, resulting in a muscular imbalance in the thoracic area of the frontal plane, that is, in scoliotic bad posture. However, these body composition parameters do not correlate with postural status in the sagittal plane, which is a consequence of the technique used to perform certain elements, namely movement activity itself, which engages muscles at the front and back thoracic areas. Further, the results obtained for non-positive body composition parameters, primarily for fat, indicate that physical activity in this group is currently insufficient, that is, that these athletes' training is at present at an unsatisfactory level. This accords with the findings of uneven distribution of muscular development, namely only in certain muscle groups, revealed via a significant correlation with fat parameters for the variable set body composition.

A limitation of this research is reflected in the inability to compare the obtained results with an adequate group of subjects of the same age and the same level of sports activity. The reason for this is the lack of research regarding the development specificities of postural disorders and body composition in blind persons who deal with sports, and especially those dealing with goalball. It can be said that this may be the first research on the connection between goalball playing and postural disorders which is the reason it was named a pilot study. Future research should consider taking into account a large number of subjects who deal with a goalball in determining the association??? of postural status and body composition. The obtained results should be compared with the population of blind people who are not physically active, and based on that, an appropriate conclusion could be made.

\section{Conclusion}

The results of this study indicate a high level of body spinal deformities in the sagittal and frontal plane as well as the existence of slightly higher levels of fat in a set of variables that describe the body composition according to respondents who are the golobists of the third international and national level of the competition. The correlation results indicate that there is a correlation between scoliotic poor posture in the thoracic part and variables that evaluate fat in the body, which can be justified by the specificity of the sport, or by technical elements of the shot at the goal. The obtained results can be consider as a starting point for further research of the postural status and body composition of goalball players.

\section{IZJAVA}

Autori su svojim izjavama potvrdili nepostojanje bilo kakvog sukoba interesa.

\section{LITERATURA}

Abdelkrim, N. B., El Fazaa, S., \& El Ati, J. (2007). Time-motion analysis and physiological data of elite under-19-year-old basketball players during competition. British Journal of Sports Medicine, 41, 69-75.

Bjorntorp, P. (1990). "Portal" adipose tissue as a generator of risk factors for cardiovascular disease and diabetes. Arteriosclerosis, Thrombosis, and Vascular Biology, 10(4), 493-496.

Bolach, E., \& Skolimowski, T. (2000). Influence of the sport team games on a posture of body of blinds and people with dimness of vision. Gymnica, 30(2), 59-63.

Bubanj, S., Živković, M., Živković, D., Milenković, S., Bubanj, R., Stanković, R., Ćirić-Mladenović, I., Stefanović, N., Purenović, T., 
Stojiljković, D., Obradović, B., Dimić, A., \& Cvetković, T. (2012) The incidence of sagittal postural deformities among high school students: preliminary study. Acta Kinesiologica, 6(2), 27-30.

Calıskan, E., Pehlivan, A., Erzeybek, M. S., Kayapınar, F. C., Agopyan, A., Yuksel, S., \& Dane, S. (2011). Body mass index and percent body fat in goalball and movement education in male and female children with severe visual impairment. Neurology, Psychiatry and Brain Research, 17(2), 39-41.

Colak,T., Bamac, B., Aydin, M., Meric, B., \& Ozbek, A. (2004). Physical fitness levels of blind and visually impaired goalball team players. Isokinetics and Exercise Science, 12, 247-252.

Demeši-Drljan, Č., \& Mikov, A. (2012). Posturalni status dece predškolskog i rano školskog uzrasta. U: M. Lazović (ured.), Zbornik radova sa 12. kongresa fizijatara Srbije sa međunarodnim učešćem (str. 65-69). Vrnjačka Banja: Udruženje fizijatara Srbije.

Farajian, P., Risvas, G., Karasouli, K., Pounis, G. D., Kastorini, C. M., Panagiotakos, D. B., \& Zampelas, A. (2011). Very high childhood obesity prevalence and low adherence rates to the Mediterranean diet in Greek children: the GRECO study. Atherosclerosis, 217(2), 525-530.

Grabara, M., \& Hadzik, A. (2009a). Postural variables in girls practicing volleyball. Biomedical Human Kinetics, 1(1), 67-71.

Grabara M., \& Hadzik, A. (2009b). The body posture in young athletes compared to their peers. Medycyna Sportowa, 25(2), 115-124.

Haroun, D., Taylor, S. J., Viner, R. M., Hayward, R. S., Darch, T. S., Eaton, S., Cole, T.J., \& Wells, J. C. (2010). Validation of bioelectrical impedance analysis in adolescents across different ethnic groups. Obesity, 18(6), 1252-1259.

Hopkins, W. G., Gaeta, H., Thomas, A. C., \& Hill, P. N. (1987). Physical fitness of blind and sighted children. European journal of Applied Physiology and Occupational Physiology, 56(1), 69-73.

Catanzariti, J. F., Salomez, E., Bruandet, J. M., \& Thevenon, A. (2001). Visual Deficiency and Scoliosis. Spine, 26(1), 48-52.

Jorgić, B., Milenković, M., Milenković, S., Stanković, R. \& Bubanj, S. (2015). The frequency of scoliotic body posture among young children in Knjaževac. In S. Pantelic (Ed). Conference proceedings of XVIII Scientific Conference, FISCommunications 2015" in physical education, sport and recreation and III International Scientific Conference (166-170). Niš: Faculty of Sport and Physical Education, University of Niš.

Jorgić, B., Đorđević, S., Belomazeva, S., Milenković, S., Tsonkova, D., Georgiev, G., \& Kostić, S. (2016). Postural status of the spinal column in the sagittal plane in a student population. In $\mathrm{S}$. Pamtelic (Ed). XIX Scientific Conference "FISCommunications 2016" in physical education, sport and recreation (295-299). Niš: Faculty of Sport and Physical Education, University of Niš.

Karaba-Jakovljević, D. (2016). Assessment methods of body composition. Praxis medica, 45(3-4), 71-77.

Mannion, A.F., Knecht, K., Balaban, G., Dvorak, J., \& Grob, D. (2004). A new skin-surface device for measuring the curvature and global and segmental ranges of motion of the spine: reliability of measurements and comparison with data reviewed from the literature. European Spine Journal, 13(2), 122-136.

Milenković, S. (2007). Korektivna gimnastika, teorija i vežbe. Niš: SIA.
Post, R.B., \& Leferink, V.J. (2004). Spinal mobility: sagittal range of motion measured with the Spinal Mouse, a new non - invasive device. Archives of Orthopedic and Trauma Surgery, 124(3), 187-192.

Scherer, R. L., Karasiak, F. C., Silva, S. G., \& Petroski, E. L. (2012). Morphological profile of goalball athletes. European Journal of Human Movement, 28, 1-13.

Slawinska, T., Rożek, K., \& Ignasiak, A. (2006). Body asymmetry within trunk at children of early sports specialization. Medycyna Sportowa, 22(161), 97-100.

Živković, D. (2009). Osnove kineziologije sa elementima kliničke kineziologije. Niš: Fakultet sporta i fizičkog vaspitanja.

Datum prijave: 24.10.2017.

Datum prihvatanja: 19.12.2017.

\section{Kontakt}

Stefan Đorđević, Univerzitet u Nišu, Fakultet sporta i fizičkog vaspitanja, Niš, Čarnojevića 10a

E-mail: stefan-djordjevic1@hotmail.com

Nebojša Mitrović, Univerzitet u Istočnom Sarajevu, Pedagoški fakultet, Republika Srpska, Bosna i Hercegovina, Bijeljina, Semberskih ratara bb E-mail: nebojsa.mitrovic@pfb.ues.rs.ba

Jovana Zrnzević, Internacionalni paraolimpijski komitet, Republika Nemačka, Bon

E-mail: jovana.zvrky@gmail.com

Martin Kudlaček, Polacki Univerzitet Olomouc, Fakultet telesne kulture, Republika Češka, Olomouc

E-mail: martin.kudlacek@upol.cz

Bojan Jorgić, Univerzitet u Nišu, Fakultet sporta i

fizičkog vaspitanja, Niš, Čarnojevića 10a

E-mail: bojanjorgic@yahoo.com 